UDC 579.84:616-036.22

DOI: $10.15587 / 2519-8025.2021 .241238$

\title{
PSEUDOMONAS AERUGINOSA AS A PRIORITY GROUP REPRESENTATIVE OF BACTERIA WITH MULTIPLE ANTIBIOTIC RESISTANCE
}

\author{
Yevheniia Vashchyk, Dmytro Morozenko, Nataliia Seliukova, Andriy Zakhariev, \\ Roman Dotsenko, Andrii Zemlianskyi, Olga Shapovalova, Ekaterina Dotsenko
}

\begin{abstract}
The aim: the aim of the research is an analytical review of the scientific literature on Pseudomonas aeruginosa as a priority group representative of bacteria with multiple antibiotics resistance.

Materials and methods. The research was conducted by the method of scientific literature open source analysis: PubMed, Elsevier, electronic resources of the National Library named after V. I. Vernadsky and others.

Results. The problem of antibiotic resistance is rightly called the "apocalypse of the XXI century".

$P$. aeruginosa bacteria are characterized by a very high natural ability to form resistant forms to antimicrobial drugs due to the formation of specific resistance genes, the ability to resist the entry of antibiotics into the cell or remove antibiotics from the cell, and form biofilms.

A characteristic feature of the epidemic and epizootic processes of P. aeruginosa, as an opportunistic ubiquitous microorganism is host-pathogenic interaction - the interaction of the pathogen with the host organism. The peculiarity of this bacterium is opportunism and long-term persistence in the body of the host and in the environment.

The global trend towards the spread of antibiotic-resistant gram-negative bacteria, including P. aeruginosa, underscores the need to develop comprehensive response strategies targeting all sectors of health.

Conclusions. Bacteria P. aeruginosa is classified in 1th Critical Group of the WHO list of resistant to antibiotics "priority pathogens". Among the main reasons that contribute to the emergence of resistance are irrational antibiotic therapy in both humans and animals, and the use of antibiotics as growth stimulants in animal husbandry.

While more $R \& D$ is vital, alone, it cannot solve the problem. To address resistance, there must also be better prevention of infections and appropriate use of existing antibiotics in humans and animals, as well as rational use of any new antibiotics that are developed in future.

New methods of combating antibiotic resistance and antibacterial substances, alternatives to antibiotics (biofilmdestroying drugs, antimicrobial peptides (AMP), bacteriophages, nanopreparations, etc.) can make a positive contribution to overcoming the multiple drug resistance of gram-negatives
\end{abstract}

Keywords: $P$. aeruginosa, antibiotic resistance, WHO, biofilm, antibiotics, multiple drug resistance

How to cite:

Vashchyk, Y., Morozenko, D., Seliukova, N., Zakhariev, A., Dotsenko, R., Zemlianskyi, A., Shapovalova, O., Dotsenko, E. (2021). Pseudomonas aeruginosa as a priority group representative of bacteria with multiple antibiotic resistance. ScienceRise: Biological Science, 3 (28), $33-40$. doi: http://doi.org/10.15587/2519-8025.2021.241238

(C) The Author(s) 2021

This is an open access article under the Creative Commons CC BY license hydrate

\section{Introduction}

Antibiotic resistance of microorganisms, according to the World Health Organization (WHO), is one of the most serious threats to human health. Bacterial resistance to antibiotics (antibiotic resistance, antimicrobial resistance - AMR) is growing every year.

The problem of acquiring antibiotic-resistant properties by pathogenic microorganisms is of great concern worldwide. The most European countries have already adopted national programs to fighting this phenomenon. The problem of fighting the spread of antibioticresistant bacteria is diverse. The search for a solution is coordinated by the World Health Organization and the $\mathrm{Bu}-$ reau International des Epizootics. Components of this problem are the control over the acquisition of antibioticresistant properties by pathogenic microorganisms and the spread of pathogenic bacteria resistant to antibiotics. Bac- teria that cause diseases in humans and productive animals are mainly monitored [1]. To address this issue, the UN adopted the Political Declaration of the High-Level Meeting of the General Assembly on Antimicrobial Resistance: resolution / adopted by the General Assembly (resolution A / RES / 71/3 of 5 October 2016). And on 26 May 2015, 68th World Health Assembly resolution WHA 68.7 approved the Global action plan on antimicrobial resistance. Ukraine is also joining the fight against this problem - on March 6, 2019, the Cabinet of Ministers of Ukraine adopted Order No. 116-r "On Approval of the National action plan on antimicrobial resistance" [2].

The level of antibiotic resistance of the main pathogens of postoperative complications in Ukraine is a serious problem. The number of strains that are resistant to one antimicrobial drug, today, on average, is $70.7 \%$, to antibiotics of $2-3$ classes $-37.5 \%$ (S. aureus $-31.4 \%$, 
E. faecalis $-37.5 \%$, E. coli-34.9\%, Enterobacter spp. $47.3 \%, P$. aeruginosa $-67.8 \%$ ), to antibiotics of 4 and more classes $-34.4 \%$ (S. aureus $-25.9 \%$, E. faecalis $31.0 \%$, E. coli $-26.3 \%$, Enterobacter spp. - $30.3 \%$, $P$. aeruginosa $-50.2 \%$ ), to all antibacterial agents $29.6 \%[3-5]$.

Pseudomonas aeruginosa - a bacterium with extraordinary properties of adaptation to external living conditions, the ability to parasitize on many members of the living world - humans, animals, plants; to exist in water, soil, disinfectant, antibacterial solutions; to form biofilms in the macroorganism, which protect the pathogen from the body's immune response and prevent the penetration of antibiotics into tissues; to remain undiagnosed due to the formation of pigment-free strains and capable of parasitizing the host for life [6-8].

The aim of the research is an analytical review of the scientific literature on Pseudomonas aeruginosa as a priority group representative of bacteria with multiple antibiotics resistance.

\section{Materials and methods}

The research was conducted by the method of scientific literature open source analysis: PubMed, Elsevier, electronic resources of the National Library named after V. I. Vernadsky.

\section{Research results}

3.1. Pseudomonas aeruginosa as a priority group representative of bacteria with multiple antibiotic resistance

WHO published its first ever list of antibioticresistant "priority pathogens" - a catalogue of 12 families of bacteria that pose the greatest threat to human health.

The list was drawn up in a bid to guide and promote research and development (R\&D) of new antibiot- ics, as part of WHO's efforts to address growing global resistance to antimicrobial medicines.

The list highlights in particular the threat of gramnegative bacteria that are resistant to multiple antibiotics. These bacteria have built-in abilities to find new ways to resist treatment and can pass along genetic material that allows other bacteria to become drug-resistant as well.

The WHO list is divided into three categories according to the urgency of need for new antibiotics: critical, high and medium priority [9].

The most critical group of all includes multidrug resistant bacteria that pose a particular threat in hospitals, nursing homes, and among patients whose care requires devices such as ventilators and blood catheters. They include Acinetobacter, Pseudomonas and various Enterobacteriaceae (including Klebsiella, E. coli, Serratia, and Proteus). They can cause severe and often deadly infections such as bloodstream infections and pneumonia (Fig. 1).

These bacteria have become resistant to a large number of antibiotics, including carbapenems and third generation cephalosporins - the best available antibiotics for treating multi-drug resistant bacteria.

The second and third tiers in the list - the high and medium priority categories - contain other increasingly drug-resistant bacteria that cause more common diseases such as gonorrhoea and food poisoning caused by salmonella.

"New antibiotics targeting this priority list of pathogens will help to reduce deaths due to resistant infections around the world", says prof Evelina Tacconelli, Head of the Division of Infectious Diseases at the University of Tübingen and a major contributor to the development of the list. "Waiting any longer will cause further public health problems and dramatically impact on patient care" [9].

(6) World Health Organization
WHO priority pathogens list for R\&D of new antibiotics
Priority 1: CRITICAL
- Acinetobacter baumannii, carbapenem-resistant
- Pseudomonas aeruginosa, carbapenem-resistant
- Enterobacteriaceae, carbapenem-resistant, ESBL-producing
Priority 2: HIGH
- Enterococcus faecium, vancomycin-resistant
- Staphylococcus aureus, methicillin-resistant, vancomycin-intermediate and resistant
- Helicobacter pylori, clarithromycin-resistant
- Campylobacter spp., fluoroquinolone-resistant
- Salmonellae, fluoroquinolone-resistant
- Neisseria gonorrhoeae, cephalosporin-resistant, fluoroquinolone-resistant
Priority 3: MEDIUM
- Streptococcus pneumoniae, penicillin-non-susceptible
- Haemophilus influenzae, ampicillin-resistant
- Shigella spp., fluoroquinolone-resistant

Fig. 1. WHO priority pathogens list for R\&D of new antibiotics

According to the Global strategy to enhance interdisciplinary collaboration and communication in all aspects of human, animal and environmental health, the concept of "One Health", the attention of veterinary and human medicine specialists is focused on the study of microorganisms that are dangerous for hu- mans, animals and plants $[10,11]$. P. aeruginosa in this aspect is an extremely important object of study, as a sapronotic microorganism, widespread in the environment, and under certain conditions, - a mediator of infectious pathology of humans, animals and plants $[12,13]$. 
The problem of bacterial resistance in animal husbandry is dangerous in that resistant strains of bacteria with resistance genes can be transmitted through food chains from farm animals and in direct contact from pets to humans. Thus, the study of the epidemic and epizootic situation of $P$. aeruginosa is an urgent issue for the further development of a highly sensitive diagnostic test system for effective protection of the population and animals in the fight against these pathogens [14].

According to the obtained data of the epidemic situation with regard to antibiotic-resistant $P$. aeruginosa strains in the world, in most countries the percentage of carbapenem-resistant strains of $P$. aeruginosa ranged from 10 to $50 \%$. Canada (carbapenems $3.3 \%$ ) and the Dominican Republic (imipenem and meropenem $8 \%$ ) have the lowest prevalence of antibiotic-resistant $P$. aeruginosa strains (less than $10 \%$ ).

Contrariwise, the percentage of antibiotic-resistant P. aeruginosa strains in Brazil, Peru, Costa Rica, Russia,
Greece, Poland, Iran and Saudi Arabia is higher than $50 \%$ to all carbapenem drugs (imipenem, meropenem, doripenem, ertapenem): it is in the range from $50 \%$ to $75.3 \%$ (Fig. 2).

In the territory of the Russian Federation, SouthWest Asia and South America, regions with a high level of antibiotic resistance predominate, which is of concern to public health professionals $[1,15]$.

Regarding the level of extensiveness of carbapenem-resistant isolates of $P$. aeruginosa in Europe, we can present the data of EARS-NET - Net database reports (Fig. 3) [1, 16].

The ecosystem of interaction between humans and animals and agriculture is dynamic, especially given the uncontrolled use of antibiotics and, as a result, the acquisition of antibiotic resistance by bacteria. It is important to study the peculiarities of the epizootic situation with regard to $P$. aeruginosa, as the pathogen is opportunistic and pathogenic to humans, almost all species of animals.

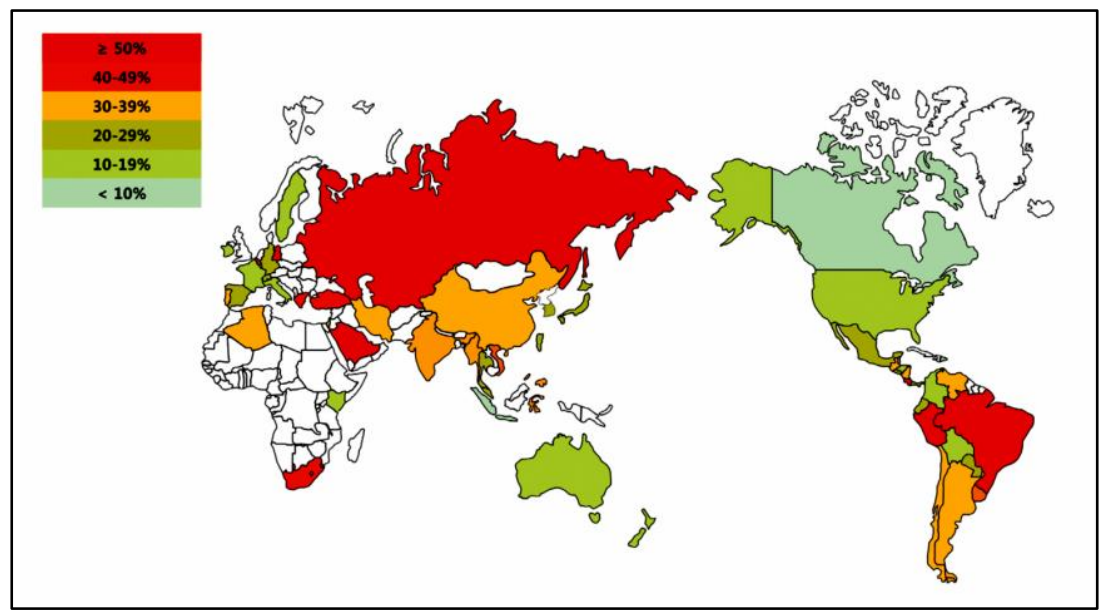

Fig. 2. Extensiveness of the epidemiological situation regarding carbapenem-resistant $P$. aeruginosa during 2009-2011 (according to Duck Jin Hong, et al., Infect Chemother 2015; 47 (2): 81-97)

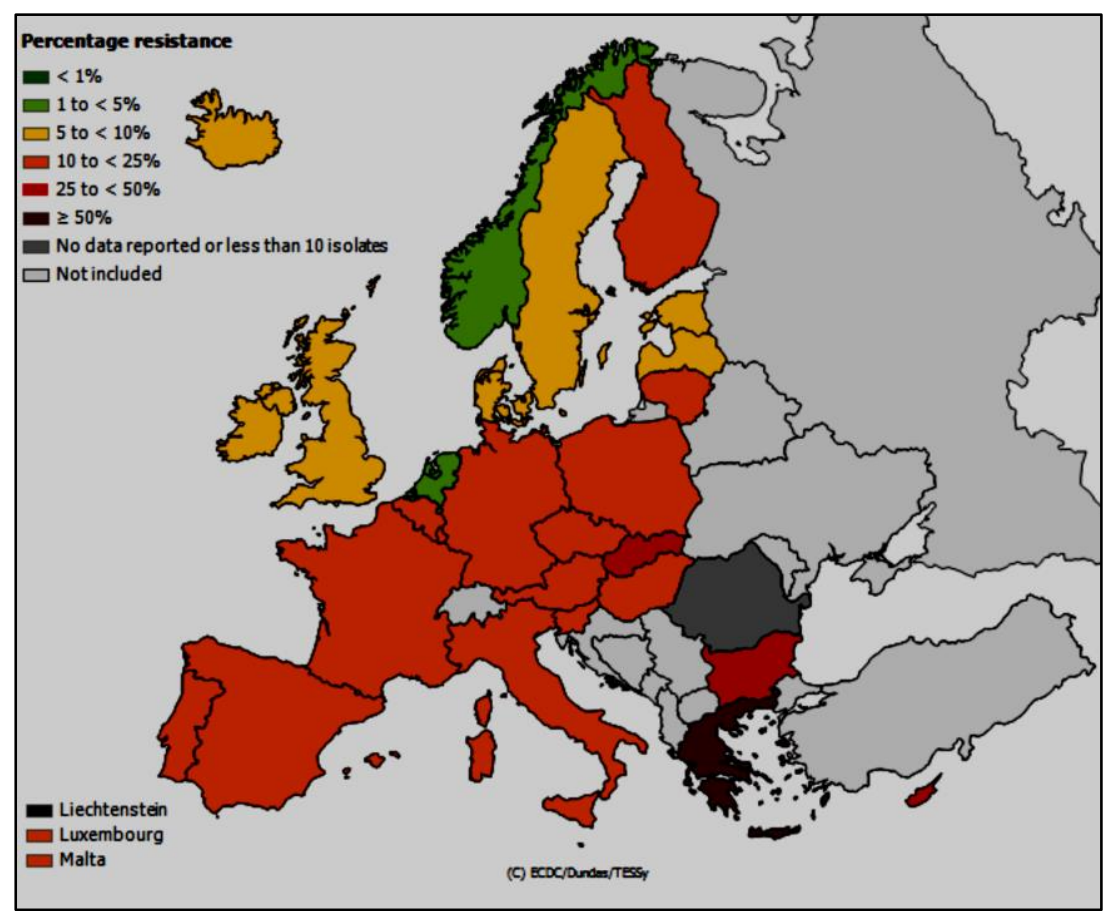

Fig. 3. Percentage of carbapenem-resistant isolates P. aeruginosa in Europe.

(According to EARS-NET reports - Net database) 
Human and different species of animals have common sources of pseudomonas infection and ways of spreading, the disease is caused by the same or very similar serological variants and groups, so Pseudomonas aeruginosa infection can be classified as zoonoses (according to World Health Organization reports) [17].

\subsection{The mechanisms of $P$. aeruginosa antibiotic} resistance development

The formation of antibiotic resistance in all cases is genetically determined by the acquisition of new genetic information, or changes in the level of expression of their own genes. Microorganisms are able to transmit information about antibiotic resistance through horizontal gene transfer (during direct contact of one bacterium with another). Bacterial plasmids are one way to transmit genetic information about resistance to antibacterial medicines. Resistance to a particular antibiotic is determined by Rplasmids (from the English «Resistance»). The mechanism of antibiotics inactivation transmitted by the plasmid is associated with the action of specific enzymes of the bacterial cell (such as $\beta$-lactamases), which are encoded by them. Plasmids can be transmitted between related genera of microorganisms. For example, the RP1-plasmid of Pseudomonas bacteria is responsible for the resistance of these microorganisms to ampicillin, tetracycline, gentamicin and can be transmitted to Escherichia coli.

The resistance of $P$. aeruginosa to antibiotics consists of several aspects. First, if necessary, the pathogen regulates the number of porins and, accordingly, the permeability of the membrane for antibiotics, also expresses a significant amount of proteins that actively remove antibiotic molecules from the cell. Second, $P$. aeruginosa, like as many other pathogens, easily acquires genes of specific resistance to various antibiotics, such as genes of $\beta$-lactamases and enzymes that inactivate aminoglycosides $[18,19]$.

Chronic P. aeruginosa infections are characterized by the formation of biofilms. Biofilms are organized complexes of microorganisms immersed in an extracellular polymer matrix, which consists of polysaccharides, proteins and DNA synthesized by these microorganisms. As part of biofilms, bacteria become more resistant to adverse environmental conditions, and to antimicrobial agents and factors of the human immune system. In this case, $P$. aeruginosa forms biofilms not only in the organs and tissues of the macroorganism, but also able to be implanted on devices and catheters [20,21].

$P$. aeruginosa has multiple medicine resistance and is even capable of contaminating antibiotic solutions. High medicine resistance of pseudomonads is due to Rplasmids, not cell chromosomes. The number of resistance markers in the 11-plasmid reaches 11-12, and all of them can be transmitted together during conjugation and transduction both within the species and between bacteria of different species and genera. Contrariwise, chromosome-related resistance occurs to only one, rarely two, antibiotic with a similar mechanism of action.

Such a high ability to transmit genetic information about antibiotic resistance within both species and genus contributes to the formation of multidrug-resistant strains of $P$. aeruginosa, which complicates the fight against this infection $[3,21]$.
Many gram-negative bacteria have resistance to $\beta$ lactams, which is associated with decreased cell wall permeability due to microbial mutations [22]. In addition, the active excretion of $\beta$-lactams from the microbial cell of enterobacteria has been proven. First of all, this mechanism is characteristic of $P$. aeruginosa, which can actively remove even carbapenems, thus protecting themselves from their influence.

Inactivation of antibiotics was demonstrated by the example of biofilm bacteria Pseudomonas aeruginosa, non-mucoid isolates of which had an increased ability to produce $\beta$-lactamases. This phenomenon led to the insensitivity of the studied biofilms to $\beta$-lactam antibiotics. Probably, such phenomena are explained by the general rule formulated for pseudomonads that are in conditions of adaptation to stressors: "All roads lead to resistance" [6].

There are numerous reports in the scientific literature of polyresistance and increasing resistance of $P$. aeruginosa isolates to previously effective antibiotics.

Resistance to piperacillin, carbenicillin, azlocillin, zeoflerazone and ticorcillin was noted. Note the high resistance of pseudomonads to penicillin, erythromycin, monomycin, ampicillin, chloramphenicol, doxycycline and low sensitivity to tetracycline and neomycin. $P$. aeruginosa has a natural sensitivity to $\beta$-lactam antibiotics (ceftazidime, cefepime, imipenem, meropenem), aminoglycosides and fluoroquinolones, which are usually effective in the treatment of pseudomonads (Oie, S., 2003; Shaginyan I. A., 2005) [23, 24].

Frequent use of aminoglycosides (gentamicin and piperacillin) causes the emergence of antibiotic-resistant mutant strains of $P$. aeruginosa with increased virulence. According to the results of our studies, the obtained isolates of $P$. aeruginosa are polyresistant to antibacterial agents and there is a tendency to significantly reduce the sensitivity of the pathogen to drugs of cephalosporins, fluoroquinolones, aminoglycosides, namely to previously effective antibiotics against this pathogen: cefpazizimide, ceftapizimide ciprofloxacin, enrofloxacin, gentamicin [25].

Specialists of the State Institution "Ukrainian Center for Disease Control and Monitoring of the Ministry of Health of Ukraine" studied 165 multidrug-resistant strains of cultures of opportunistic pathogens, probable pathogens of nosocomial infections, the composition of which is as follows: A. baumannii - $29.1 \%$, P. aeruginosa - $26.1 \%$, K. pneumoniae - $12.7 \%$, S. haemolyticus $-12.7 \%$, E. cloacae $-7.9 \%$, E. coli $7.4 \%$, S. aureus $-1.8 \%$, others $-2.3 \%$.

It was noted that $64 \%$ of $P$. aeruginosa strains isolated from wounds were resistant to ceftazidime, $75 \%$ to cefepimine, $80 \%$ to ciprofloxacin, $92 \%$ to colistin. Strains of $P$. aeruginosa isolated from blood had $100 \%$ resistance to cotrimoxazole, ciprfloxacin and in $50 \%$ of cases - to piperacillin, ceftazidime, cefepemine, amikacin, gentamicin, tobramycin [26].

The adaptive abilities of $P$. aeruginos $a$ in the nosocomial environment are associated with the dominance of antibiotic-resistant isolates characterized by the absence of aggressive virulence factors, such as clones ST111, ST-175, ST-235, which are responsible for nosocomial infections caused by multidrug-resistant strains 
$P$. aeruginosa worldwide. Such clones are associated with impaired production of piocyanin and pioverdin, also have mobility defects. It is likely that such strains are unfavourable metabolically or in terms of activating their host immune system. Changes in metabolism help to limit the access of nutrients and oxygen to cells, which is fully maintained in the biofilm, where bacteria are prone to slow growth or existence in the stationary phase. Thus, the lack of pigment, levelling of mobility, resistance to antibiotics and biofilm formation contribute to the successful survival and spread of adapted $P$. aeruginosa in hospital [27, 28].

The results of our previous studies also show that among pigment-free isolates, compared to those that synthesize pigment, antibiotic-resistant is found to be $28 \%$ higher, and pathogenic against chickens - by $12.5 \%$. $P$. aeruginosa isolates obtained by association with bacterial pathogens are characterized by a high level of viability (cultures do not lose pathogenic, biochemical and enzymatic properties for three years on MPA under rubber crusts at a temperature of $4-5{ }^{\circ} \mathrm{C}$ without reseeding). We have established the ability of bacteria to suppress and restore pigmentation, which complicates the diagnosis and contributes to the spread of latent forms of infection [25].

\section{sistance}

\subsection{Finding ways of fight against antibiotic re-}

Global leaders and experts today called for a significant and urgent reduction in the amounts of antimicrobial drugs, including antibiotics, used in food systems recognizing this as critical to combatting rising levels of drug resistance.

The Global Leaders Group on Antimicrobial Resistance- today called upon all countries to significantly reduce the levels of antimicrobial drugs used in global food systems. This includes stopping the use of medically important antimicrobial drugs to promote growth in healthy animals and using antimicrobial drugs more responsibly overall.

The call comes ahead of the UN Food Systems Summit which takes place in New York on 23 September 2021 where countries will discuss ways to transform global food systems.

A top priority call to action is to use antimicrobial drugs more responsibly in food systems and markedly reduce the use of drugs that are of greatest importance to treating diseases in humans, animals and plants.

Other key calls to action for all countries include:

- ending the use of antimicrobial drugs that are of critical importance to human medicine to promote growth in animals.

- limiting the amount of antimicrobial drugs administered to prevent infection in healthy animals and plants and ensuring that 11 use is performed with regulatory oversight.

- eliminating or significantly reducing over-thecounter sales of antimicrobial drugs that are important for medical or veterinary purposes.

- reducing the overall need for antimicrobial drugs by improving infection prevention and control, hygiene, biosecurity and vaccination programmes in agriculture and aquaculture.
- ensuring access to quality and affordable antimicrobials for animal and human health and promoting innovation of evidence based and sustainable alternatives to antimicrobials in food systems.

Inaction will have dire consequences for human, animal, plant and environmental health. Drug-resistant diseases already cause at least 700,000 human deaths globally every year [17].

Pseudomonas aeruginosa is one of the most common and problematic opportunistic pathogens, capable of colonizing various organs and tissues of humans and animals, and is often resistant to many antibiotics used in clinical practice. This resistance may be associated with the emergence of specific resistance genes, with the ability to resist the entry of antibiotics into the cell, as well as the formation of biofilms. In this regard, scientists are currently actively exploring the possibility of creating compounds that differ in mechanism of action from conventional antibiotics (which have bactericidal or bacteriostatic action), aimed at reducing the ability of the pathogen to colonize and damage human or animal tissues by inhibiting virulence factors and inhibition of biofilm formation.

A combination of several types of antibiotics. The classic use of antibiotics, which has been found ineffective for use in biofilms, could also be modified to achieve positive dynamics. Simultaneous use of several types of antibiotics that act on fundamentally different targets of the bacterial cell and could cover the metabolic diversity of a heterogeneous population in the biofilm can be effective.

The M.C. Walters et al. (2003) achieved a positive effect against $P$. aeruginosa biofilms with the combined use of tobramycin, ciprofloxacin and tetracycline, which act on physiologically active cells in the upper layer of the biofilm, and the antibiotic colistin, which can affect metabolically inactive cells. The parallel use of antibiotics with SDS detergent and EDTA chelating agent also had a positive effect [20,21].

$P$. aeruginosa lectins as targets for new antibacterial compounds. One of the popular approaches aimed at combating antibiotic resistance of $P$. aeruginosa involves the development of compounds that kill pathogenic bacteria not by inhibiting biosynthesis, but by inhibiting or inactivating their virulence factors: toxins, adhesins, effector proteins that modulate metabolism and host, and secretion systems that deliver these proteins to the site of action, as well as factors that promote the communication of bacteria with each other and their formation of biofilms [21, 29].

Lectins of $P$. aeruginosa LecA and LecB, soluble proteins that bind galactose (LecA) and fucose (LecB) residues separately and as part of oligo- and polysaccharides, are considered as one of the targets for such antivirulent compounds. These proteins are involved in the attachment of the pathogen to the cells of the macroorganism, because of damage to epithelial tissues, and also play a significant role in the formation of biofilms of $P$. aeruginosa, thus acting as important virulent factors [30].

Lectins LecA and LecB, apparently, belong to those virulent factors of $P$. aeruginosa, which allow this microorganism to colonize human tissues and organs and persist in them as part of biofilms, cause the development 
of chronic diseases that are difficult to treat. The use of appropriate monosaccharides and multivalent glycoclusters in animal models of $P$. aeruginosa infection convincingly shows a positive effect of inhibition of both lectins, which is confirmed by clinical data [21,31].

Combining different strategies to combat biofilms. Any of the considered strategies of biofilm therapy - the use of anti-adhesive or biofilm-destructive drugs, leads to the return of biofilm culture to the plankton state. In this condition, the cells often "reverse" to a high level of sensitivity to antibiotics, so they can be subjected to standard therapies [20, 23, 24].

An example of such combination therapy may be the simultaneous use of alginate lyase and DNAase, which destroy the matrix of $P$. aeruginosa biofilms, in combination with the antibiotic tobramycin. It is shown that this approach increases the sensitivity of biofilms to antibiotics, respectively, requires less long-term antibiotic therapy and does not allow for the selection of resistant cells and the transition to a chronic form of infection $[32,33]$.

Bacteriophagy. Bacteriophages are specific and do not affect eukaryotic cells, inducing bacteriolysis as mechanisms other than antibiotics. Cases of a positive result of treatment of bacteremia of mice caused by carbapenem-resistant strains of $P$. aeruginosa when using specific virulent strains of bacteriophages have been described [27, 34].

Use of antimicrobial peptides (AMP). AMP is a diverse group of molecules that are produced by many tissues and cell types of various invertebrates, plants and animals. Most AMPs are small, cationic, and amphiphilic, and are an important component of innate immune defence: Host defence peptides (HDPS). The mechanism of action of AMP is to kill bacteria by forming pores in cell membranes, some of the peptides inhibit the function of intracellular biopolymers. AMP OH-CATH30 from the king cobra showed a synergistic effect with ciprofloxacin and levofloxacin against $P$. aeruginosa $[35,36]$.

Nanotechnology. Inorganic substances in the form of nanoparticles have a promising direction as antimicrobial agents. Nanosized materials have a large surface area relative to the volume, which leads to increased reactivity. The bactericidal activity of silver nanoparticles against strains of $P$. aeruginosa, A. baumannii and the ability to prevent the formation of biofilms have been shown [37].

Our proposed method of prevention of associated pseudomonosis of poultry embryos by rotating environmentally friendly products made on the principles of nanotechnology (3\% solution "Sumerian silver" and
$0.03 \%$ solution "VetOx 1000") provides 1.1-1.7\% higher hatching of young compared to the control with the use of formalin [25].

\section{Conclusions}

The problem of antibiotic resistance is rightly called the "apocalypse of the XXI century".

$P$. aeruginosa bacteria are characterized by a very high natural ability to form resistant forms to antimicrobial drugs due to the formation of specific resistance genes, the ability to resist the entry of antibiotics into the cell or remove antibiotics from the cell, and form biofilms. Bacteria $P$. aeruginosa is classified in 1th Critical Group of the WHO list of resistant to antibiotics "priority pathogens". Among the main reasons that contribute to the emergence of resistance are irrational antibiotic therapy in both humans and animals, and the use of antibiotics as growth stimulants in animal husbandry.

A characteristic feature of the epidemic and epizootic processes of $P$. aeruginosa, as an opportunistic ubiquitous microorganism is host-pathogenic interaction - the interaction of the pathogen with the host organism. The peculiarity of this bacterium is opportunism and long-term persistence in the body of the host and in the environment.

The global trend towards the spread of antibioticresistant gram-negative bacteria, including $P$. aerugino$s a$, underscores the need to develop comprehensive response strategies targeting all sectors of health.

While more R\&D is vital, alone, it cannot solve the problem. To address resistance, there must also be better prevention of infections and appropriate use of existing antibiotics in humans and animals, as well as rational use of any new antibiotics that are developed in future.

New methods of combating antibiotic resistance and antibacterial substances, alternatives to antibiotics (biofilm-destroying drugs, antimicrobial peptides (AMP), bacteriophages, nanopreparations, etc.) can make a positive contribution to overcoming the multiple drug resistance of gram-negatives.

\section{Acknowledgment}

The authors thank the staff of the toxicological monitoring laboratory.

\section{Conflict of interests}

The authors declare that they have no conflicts of interest.

\section{Financing}

The study was performed without financial support.

\section{References}

1. Novhorodova, O. Yu., Ushkalov, V. O., Mazur, T. V. (2017). The features of the epidemic and episootic situation of the Pseudomonas Aeruginosa. Naukovi dopovidi NUBiP Ukrainy, 3 (67).

2. Pro zatverdzhennia Natsionalnoho planu dii shchodo borotby iz stiikistiu do protymikrobnykh preparativ (2019). Rozporiadzhennia Kabinetu Ministriv Ukrainy No. 116-r. 06.03.2019. Available at: https://zakon.rada.gov.ua/laws/card/116-2019-\%D1\%80

3. Romaniuk, L. B., Kravets, N. Ia., Klimniuk, S. I., Kopcha, V. S., Dronova, O. I. (2019). Antibiotic-resistance of opportunistic microorganisms: topicality, conditions of emergency, ways of overcome. Infektsiini khvorobi, 4 (98), 63-71. doi: http://doi.org/10.11603/1681-2727.2019.4.10965

4. Shyrobokov, V. P. (2011). Medychna mikrobiolohiia, virusolohiia, imunolohiia. Vinnytsia: Nova knyha, 952.

5. Klymniuk, S. I., Romaniuk, L. B., Kravets, N. Ya. (2019). Mikrobnyi peizazh rotohlotky khvorykh na kir ditei ta antybiotykochutlyvist vydilenykh shtamiv. Dovkillia i zdorovia. Ternopil: TDMU Ukrmedknyha, 122-123.

6. Beliakov, V. D., Riapis, L. A., Iliukhin, V. I. (1990). Psevdomonady i psevdomonozy. Moscow: Meditsina, 223. 
7. Salimi, H., Owlia, P., Yakhchali, B., Rastegar L, A. (2009). Drug Susceptibility and Molecular Epidemiology of Pseudomonas aeruginosa Isolated in a Burn Unit. American Journal of Infectious Diseases, 5 (4), 301-306. doi: http://doi.org/10.3844/ajidsp.2009.301.306

8. Zon, H. A., Vashchyk, Ye. V. Stets, V. V. (2011). Metodychni rekomendatsii z diahnostyky, zakhodiv borotby ta profilaktyky psevdomonozu ptytsi. Sumy.

9. WHO publishes list of bacteria for which new antibiotics are urgently needed (2017). Available at: https://www.who.int/news/item/27-02-2017-who-publishes-list-of-bacteria-for-which-new-antibiotics-are-urgently-needed

10. Sikkema, R., Koopmans, M. (2016). One Health training and research activities in Western Europe. Infection Ecology \& Epidemiology, 6 (1), 33703. doi: http://doi.org/10.3402/iee.v6.33703

11. Animal Production Food Safety. World Organization for Animal Health (OIE). Available at: https://www.oie.int/en/whatwe-do/global-initiatives/food-safety/oie-activities/

12. Food-borne zoonoses (2014). European Food Safety Authority. Available at: https://www.efsa.europa.eu/sites/default/files/ corporate_publications/files/factsheetfoodbornezoonoses2014_en.pdf

13. Rabinowitz, P. M., Natterson-Horowitz, B. J., Kahn, L. H., Kock, R., Pappaioanou, M. (2017). Incorporating one health into medical education. BMC Medical Education, 17 (1). doi: http://doi.org/10.1186/s12909-017-0883-6

14. Sadikot, R. T., Blackwell, T. S., Christman, J. W., Prince, A. S. (2005). Pathogen-Host Interactions in Pseudomonas aeruginosa Pneumonia. American Journal of Respiratory and Critical Care Medicine, 171 (11), 1209-1223. doi: http://doi.org/10.1164/ rccm.200408-1044so

15. Hong, D. J., Bae, I. K., Jang, I.-H., Jeong, S. H., Kang, H.-K., Lee, K. (2015). Epidemiology and Characteristics of Metallo- $\beta$ Lactamase-Producing Pseudomonas aeruginosa. Infection \& Chemotherapy, 47 (2), 81-97. doi: http://doi.org/10.3947/ic.2015.47.2.81

16. ECDC Surveillance Atlas - Antimicrobial resistance. Available at: https://atlas.ecdc.europa.eu/public/index.aspx? Dataset $=27 \&$ HealthTopic $=4$

17. World leaders and experts call for significant reduction in the use of antimicrobial drugs in global food systems (2012). Available at: https://www.who.int/news/item/24-08-2021-world-leaders-and-experts-call-for-significant-reduction-in-the-use-of-antimicrobial-drugsin-global-food-systems

18. Salimi, H., Owlia, P., Yakhchali, B., Rastegar L, A. (2009). Drug Susceptibility and Molecular Epidemiology of Pseudomonas aeruginosa Isolated in a Burn Unit. American Journal of Infectious Diseases, 5 (4), 301-306. doi: http://doi.org/10.3844/ajidsp.2009.301.306

19. Melezhik, I. A., IAvorskaia, N. V., SHepelevich, V. V., Kokozei, V. N. (2013). Rol bioplenok Rseudomonas aeruginosa v razvitii endogennykh infektsii. Biulleten Orenburgskogo nauchnogo tsentra UrO RAN, 3. Available at: http://elmag.uran.ru:9673/magazine/ Numbers/2013-3/Articles/5Melezhik(2013-3).pdf

20. Yanagihara, K., Tomono, K., Sawai, T., Kuroki, M., Kaneko, Y., Ohno, H., Kohno, S. J. et. al. (2000). Combination therapy for chronic Pseudomonas aeruginosa respiratory infection associated with biofilm formation. Journal of Antimicrobial Chemotherapy, 46 (1), 69-72. doi: http://doi.org/10.1093/jac/46.1.69

21. Grishin, A. V., Krivozubiv, M. S., Kariagina, A. S., Ginzburg, A. L. (2015). Lektiny Pseudomonas aeruginosa kak misheni dlia novykh antibakterialnykh soedinenii. ACTA NATURAE, 7 (2 (25)), 32-45.

22. Minukhin, V. V., Zviahintseva, T. V. (2014). Antybiotykorezystentnist. Suchasnyi pohliad na problemu ta shliakhy podolannia. Kharkiv: KhNMU, 16.

23. Baturin, V. A., Schetinin, E. V, Demidenko, I. F., Korableva, O. A., Baturina, M. V., Savchenko, T. A., Kunitsyna, E. A. (2014). Biulleten antibiotikorezistentnosti respiratornykh patogenov v OITAR g. Stavropolia. Stavropol: Izd. StGMU.

24. Abaev, Iu. K. (2006). Vnutribolnichnaia infektsiia v neonatologii. Meditsinskie novosti, 11, 37-43.

25. Vashchyk, Ye. V. (2019). Teoretychno-eksperymentalne obgruntuvannia systemy kontroliu asotsiiovanoho perebihu psevdomonozu ptytsi. Kharkiv, 42.

26. Harkavenko, T. O., Nevolko, O. M., Ordynska, D. O., Mezhenska, N. A., Kozytska, T. H. (2015). Antybiotykorezystentnist mikroorhanizmiv. Veterynarna medytsyna Ukrainy, 3 (229), 13-16.

27. Markelova, N. N., Semenova, E. F. (2018). Possible Ways to Overcome Antibiotic Resistance of Nosocomial Pathogens Klebsiella pneumoniae, Acinetobacter baumannii, Pseudomonas aeruginosa, Stenotrophomonas maltophilia. Antibiotics and Chemotherapy, 63 (11-12), 45-54.

28. Walters, M. C., Roe, F., Bugnicourt, A., Franklin, M. J., Stewart, P. S. (2003). Contributions of Antibiotic Penetration, Oxygen Limitation, and Low Metabolic Activity to Tolerance of Pseudomonas aeruginosa Biofilms to Ciprofloxacin and Tobramycin. Antimicrobial Agents and Chemotherapy, 47 (1), 317-323. doi: http://doi.org/10.1128/aac.47.1.317-323.2003

29. Clatworthy, A. E., Pierson, E., Hung, D. T. (2007). Targeting virulence: a new paradigm for antimicrobial therapy. Nature Chemical Biology, 3 (9), 541-548. doi: http://doi.org/10.1038/nchembio.2007.24

30. Avichezer, D., Katcoff, D. J., Garber, N. C., Gilboa-Garber, N. (1992). Analysis of the amino acid sequence of the Pseudomonas aeruginosa galactophilic PA-I lectin. Journal of Biological Chemistry, 267 (32), 23023-23027. doi: http://doi.org/10.1016/s0021-9258(18)50050-8

31. Gilboa-Garber, N., Katcoff, D. J., Garber, N. C. (2000). Identification and characterization of Pseudomonas aeruginosaPA-IIL lectin gene and protein compared to PA-IL. FEMS Immunology \& Medical Microbiology, 29 (1), 53-57. doi: http://doi.org/10.1111/j.1574-695x.2000.tb01505.x

32. Yegorova, O. N. (2010). Pseudomonas aeruginosa-induced Infections in the Intensive Care Unit. General Reanimatology, 6 (5), 51-54. doi: http://doi.org/10.15360/1813-9779-2010-5-51

33. Reshedko, G. K., Riabova, E. L. Krechikova, O. I. (2007). Rezistentnost k antibiotikam gramotritsatelnykh vozbuditelei nozokomialnykh infektsii v ORIT. Klin. mikrobiologiia i antimikrob. khimioterapiia, 2, 163-179.

34. Wang, J., Hu, B., Xu, M., Yan, Q., Liu, S., Zhu, X. et. al. (2006). Use of bacteriophage in the treatment of experimental animal bacteremia from imipenem-resistant Pseudomonas aeruginosa. International Journal of Molecular Medicine, 17 (2), $309-317$. doi: http://doi.org/10.3892/ijmm.17.2.309

35. Li, X., Z. Zhang, L., McKay, G. A., Poole, K. (2003). Role of the acetyltransferase AAC (6 )-Iz modifying enzyme in aminoglycoside resistance in Stenotrophomonas maltophilia. Journal of Antimicrobial Chemotherapy, 51 (4), 803-811. doi: http://doi.org/10.1093/jac/dkg148 
36. Pucci, M. J., Bush, K. (2013). Investigational Antimicrobial Agents of 2013. Clinical Microbiology Reviews, 26 (4), 792-821. doi: http://doi.org/10.1128/cmr.00033-13

37. Rai, M. K., Deshmukh, S. D., Ingle, A. P., Gade, A. K. (2012). Silver nanoparticles: the powerful nanoweapon against multidrug-resistant bacteria. Journal of Applied Microbiology, 112 (5), 841-852. doi: http://doi.org/10.1111/j.1365-2672.2012.05253.x

Received date 17.08.2021

Accepted date 14.09.2021

Published date 30.09.2021

Yevheniia Vashchyk*, Doctor of Veterinary Sciences, Associate Professor, Department of Veterinary Medicine and Pharmacy, National University of Pharmacy, Pushkinska str., 53, Kharkiv, Ukraine, 61002

Dmytro Morozenko, Doctor of Veterinary Sciences, Senior Researcher, Head of Department, Department of Veterinary Medicine and Pharmacy, National University of Pharmacy, Pushkinska str., 53, Kharkiv, Ukraine, 61002

Nataliia Seliukova, Doctor of Biological Sciences, Associate Professor, Department of Veterinary Medicine and Pharmacy, National University of Pharmacy, Pushkinska str., 53, Kharkiv, Ukraine, 61002

Andriy Zakhariev, PhD, Associate Professor, Department of Veterinary Medicine and Pharmacy, National University of Pharmacy, Pushkinska str., 53, Kharkiv, Ukraine, 61002

Roman Dotsenko, PhD, Senior Researcher, Associate Professor, Department of Veterinary Medicine and Pharmacy, National University of Pharmacy, Pushkinska str., 53, Kharkiv, Ukraine, 61002

Andrii Zemlianskyi, PhD, Assistant, Department of Veterinary Medicine and Pharmacy,National University of Pharmacy, Pushkinska str., 53, Kharkiv, Ukraine, 61002

Olga Shapovalova, $\mathrm{PhD}$, Senior Researcher, Associate Professor, Department of Microbiology, Virology and Immunology, National University of Pharmacy, Pushkinska str., 53, Kharkiv, Ukraine, 61002

Ekaterina Dotsenko, PhD, Senior Researcher, Laboratory "Veterinary sanitation and parasitology", National scientific center «Institute of Experimental and Clinical Veterinary Medicine», Pushkinska str., 83, Kharkiv, Ukraine, 61023

*Corresponding author: Yevheniia Vashchyk, e-mail: yevgeniavashik@gmail.com 